\title{
School Readiness for Gifted Children: Considering the Issues
}

\author{
Marion Porath \\ The University of British Columbia
}

\begin{abstract}
This paper discusses issues relevant to gifted children's readiness for school. It raises a number of questions that challenge thinking about what is meant by school readiness. Gifted children can often be ready for school entrance before the age traditionally considered appropriate. Their complex developmental profiles challenge accepted notions of school readiness. Questions and issues pertaining to how giftedness is defined and nurtured, determination of socialemotional readiness for school, and development of giftedness across the life span are considered for their educational implications. Findings from developmental psychology on transition points in development, predictability of intelligence, and motivation to learn are presented as a framework for thinking about educational policy and practice that best support young children with learning profiles that include advanced levels of development. Questions raised also constitute directions for research on a topic that lacks a solid research base.
\end{abstract}

Lucas, an engaging 5-year-old, had read all of J. R. R. Tolkien's books by the time he entered kindergarten and was eagerly searching for another author who wrote similar books. He loved challenging himself with multiple digit multiplication and division problems and was fascinated by infinity and mathematical patterns in the natural world. Socially, he found it hard to make friends at kindergarten. Despite his sociable personality, his advanced interests and vocabulary made it difficult to find friends among his age peers. Early in Grade 1, these differences became even more apparent and Lucas stepped up his efforts to find like-minded friends. He tried socializing with older students at recess and lunch with short-term success. The novelty soon wore off for the older children. Next, he talked to the librarian and teachers, preferring adult company to that of his peers. Lucas was clearly ready for the academic aspects of school-more than ready since his academic achievement was already like that of much older students. He was socially and emotionally ready, eager to join in the social world of school. He was healthy and well adjusted. What constitutes school readiness for a child like Lucas? He was clearly ready for school, but was school ready for him? 
This paper challenges traditional understandings of school readiness through consideration of the developmental profiles of gifted children and examines the potential mismatch between characteristics of children considered gifted and what school offers in the early years. In doing so, it also challenges prevalent notions about giftedness and the educational structures in place to support gifted learners. For example, should Lucas have started school earlier than he did? What factors might have supported a decision to allow early entry? What factors might have led to opposition to early entrance? How do our understandings of advanced development inform such decisions? Does the decision concentrate on identifying Lucas as gifted or supporting him in continuing to develop optimally? What kinds of academic and social-emotional support should be offered to Lucas as an early entrant to school? As an 'age typical' entrant? The paper presents a series of provocations (Rodari, 1973) for dialogue about best practice and research into what school readiness means for children who challenge notions of what it means to be ready for school. These provocations highlight what educators need to consider, debate, and research to further our understanding of appropriate education for gifted young children.

School readiness is generally understood to mean cognitive, linguistic, social, emotional, and physical readiness to begin school (Doherty, 1997), meet the demands of school, and benefit from educational activities (School Readiness to Learn Project, 2010). Young children's ability to adjust to school routines and expectations for conduct predict successful learning (Eisenberg, 1992), and the quality of their relationships with their peers and teachers influences their motivation to learn (Junoven \& Wentzel, 1996) and predicts academic achievement (Caprara, Barbaranelli, Pastorelli, Bandura, \& Zimbardo, 2000). Attention has focused on supporting children with special needs to enter school with appropriate support (Janus, Hughes, \& Duku, 2010), but gifted children are largely excluded from this consideration despite the inclusion of giftedness in most provincial definitions of special needs. Gifted children do have special needs that need to be thought through carefully in order to ensure successful school careers.

All children have unique developmental pathways that need to be considered upon school entry in order to facilitate optimal development of potential. The task is more complex when developmental advancement is part of a child's learning profile. Schools tend to think of classrooms as homogeneous "by virtue of chronological age" (Tomlinson et al., 2003, p. 119) when, in fact, classrooms reflect the diversity of human development and culture, including the reality of children who are "more than ready" for school. One of the suggested strategies to support these children is to facilitate their early entrance to school.

\section{Early School Entrance}

While early school entrance may be suggested for gifted young children, there is little research on its effects. Early research showed generally positive results for both academic and social outcomes (Birch, 1954; Hobson, 1948; Reynolds, 1962). More recent research confirms those findings while recognizing that decisions need to be made on an individual basis (Neihart, 2007) and that school and family support and sensitivity to the needs of the young gifted child are important in ensuring success (Janos \& Robinson, 1985). Academic effects of acceleration are strongest; social-emotional effects are weaker and do not indicate a particular advantage (Neihart, 2007). On the other hand, failure to accelerate can have negative effects such as behavioural difficulties and lack of interest in learning (Keating, 1991; Neihart, 2007). It is advised that young children be carefully screened before early entrance to school is considered (Colangelo, Assouline, \& Gross, 2004). However, the question of what should be screened for is critical. Social readiness, emotional maturity, motivation for acceleration (Neihart, 2007), and physical 
readiness (i.e., stamina and fine motor control; Colangelo et al., 2004) are seen as important. However, determination of what these mean, in practice, is sometimes difficult. Systemic resistance to early entrance in schools can influence adult perceptions of readiness factors (Southern \& Jones, 1991). Furthermore, readiness factors interact with school and family influences (Goelman et al., 2003), making prediction of success difficult.

A related issue affecting decisions about early school entry is that while the early years of development and schooling are recognized as critically formative, a substantive body of research on young gifted children and primary education appropriate to their needs has yet to accrue (Robinson, 2000). Research is needed in the contexts of contemporary schooling and current understandings of the nature of giftedness that addresses questions such as: What do we mean by giftedness? What do we know about early development of giftedness than can inform our consideration of appropriate early schooling? Does Lucas need to be formally identified as gifted to have his needs met? What do we know about schooling that may affect its match to the developmental needs of gifted children? If early entrance is considered for a child who is more than ready for school, then what should be in place to provide optimal support for that child?

\section{What is Giftedness?}

Current conceptions of giftedness recognize the different ways in which one can be intelligent (e.g., Gardner, 1983; Liben, 2009; Matthews \& Foster, 2009; Sternberg \& Davidson, 2005; Winner, 2009). These conceptions represent the move away from a narrow view of "global intelligence," usually communicated as an intelligence quotient (IQ) that has little utility for educational decisions (Keating, 1991; Matthews \& Foster, 2009) and is seen as absolutist (an "absolute state of being;" Dai, 2010) - a trait definition. Contemporary views favour developmental models of giftedness that describe giftedness as developmental advancement (Keating, 1991), developmental diversity (Dai, 2010), and "dynamic, contextual, and emergent" (Dai, 2010 , p. 21) - a state definition. A developmental definition is more readily translated into educational implications. By knowing the extent of a child's developmental advancement, appropriate curricular options can be planned (Keating, 1991; Matthews \& Foster, 2009). Thus, Lucas's advanced reading and mathematical abilities are much more important guidelines for appropriate curricula than his IQ.

Similarly, understanding that developmental advancement may change over the school years - the dynamic aspect of giftedness that involves changing demands, passions, and motivations - translates into the need to be responsive to the contextual and emergent aspects of development as children mature (Jackson, 2000). The compelling need for advanced reading and mathematics curricula for Lucas in the primary grades may change as he matures. Lucas, at 6, recognized that he needed to prepare for 'multiple careers,' partly because he was interested in many things but also because he knew that career choice no longer implies a single path. It is quite possible that some aspects of his schooling will change over time; for example, the need for advanced mathematics curriculum may be replaced by early and intensive involvement in advanced science.

Gifted learners can be developmentally advanced in one or more areas (intellectual, academic, artistic, social, emotional, musical, and/or physical) and may also be extraordinarily creative. As compared to their peers, gifted children learn more, learn faster, and reason more complexly and abstractly in their area(s) of strength (Porath, 2009). However, they are not a homogeneous group. Likely because of their high intelligence(s) and strong desire to explore and master domains of interest (Winner, 1996) they are a complex and diverse group. They show 
significant within-group diversity (Robinson, 1987) in intellectual (Lubinski \& Benbow, 2000; Robinson, Zigler, \& Gallagher, 2000) and nonintellectual (motivation and self-concept) attributes (Lubinski \& Benbow, 2000). This diversity is particularly important to acknowledge in early childhood where the mix of developmental levels can make educational decisions difficult. Thus, a 5-year-old who is capable of doing mathematics at a Grade 7 level may, at the same time, "act her age" when she does not get what she wants. A 6-year-old may ask probing questions about the natural world but read at or below grade expectations. A 4.5-year-old may read at a 12-year-old level but not understand all of what she reads because abstract conceptual understanding is related to maturation (Fischer \& Canfield, 1986; Porath, 1992). In addition, the emotional impact of what she reads may be inappropriate for a 4.5-year-old. The possible variety of developmental levels in gifted children is enormous, causing some to define giftedness as asynchronous development (Morelock, 1996). This asynchronicity can make educational planning challenging.

Another way in which heterogeneity is evident is the multiple pathways to giftednesscomplex development means a variety of ways to learn and problem solve - and multiple ways of demonstrating giftedness in any one domain. Each child's developmental trajectory is unique (Fischer, Knight, \& Van Parys, 1993; Golomb, 1992; Porath, 1993, 2000; Robinson, 1993) with individual differences in "developmental timing of the emergence of giftedness" (Gottfried, Gottfried, \& Guerin, 2009, p. 52).

\section{Early Emergence of Giftedness}

Giftedness may be evident very early in development. Observations and behavioural ratings done from ages 1 through 8 (e.g., scales of infant development, parent ratings, intrinsic motivation inventories) are good predictors of intellectual and academic precocity (Gottfried, Gottfried, Bathurst, \& Guerin, 1994; Louis \& Lewis, 1992). Linguistic and mathematical precocity are evident in very young children and remain stable over time (Dale, Robinson, \& CrainThoresen, 1995; Robinson, Abbott, Berninger, \& Busse, 1996). Similarly, artistic and musical precocity (Feldman, 1986; Golomb, 1992) are demonstrated in very early childhood. As Robinson (2000) noted, these children "do not catapult into school without histories" (p. 7). They bring with them complex, sophisticated ways of understanding and intense, focused interests.

\section{Exceptional Intrinsic Motivation}

Young children with learning profiles that include developmental advancement often demonstrate intense interest and drive in their areas of strength (Gottfried et al., 1994; Robinson, 1993). Winner (1996) characterized this exceptional intrinsic motivation as "rage to master" (p. 3). Consider young gifted mathematicians. Waxman, Robinson, and Mukhopadhyay (1996) found that 5- to 7-year-olds with advanced levels of mathematical ability stayed absorbed with problems for long periods of time; persevered when they found problems difficult to solve; and connected many things in their daily lives to mathematics. They essentially 'lived and breathed' mathematics.

Young gifted children demonstrate intense motivation to learn, but what do they understand about school as a place of learning and the experience of entering school early? Motivation for acceleration is considered one of the criteria for which to screen when a decision needs to be made about accelerated learning (Tomlinson et al., 2003). How would their motivation for acceleration be elicited at this young age? It is critical to ascertain children's perspectives, 
particularly how they understand school and the learning that takes place there (Porath \& Lupart, 2009). What are their understandings of grade placement and what it would mean to be in a class with older children for either all or part of their school day? Young gifted children have little experience of school and are likely to understand it in very concrete terms (Porath \& Lupart, 2009). However, despite their concrete and limited knowledge, children's perspectives on school must be elicited and respected. In general, they are largely left out of educational decisions (Bruner, 1996); similarly, their ways of understanding are rarely incorporated in our thinking about their education, despite the value of knowing how and what they think about themselves as learners and their school involvement (Dweck \& London, 2004; Porath \& Lupart, 2009).

Ethan, aged 6, when asked about his identity as a learner, replied, "I like reading. I love it! I'm reading a chapter book about Star Wars....I like to draw lots. Draw and read. I like reading more" (Porath \& Lupart, 2009, p. 86). This passion for learning can be kept alive and extended through educational experiences well matched to Ethan's abilities. There are key points in development "at which talent may be derailed or may flourish" (Dweck, 2009, p. xii). These points may be related to changes in task demands or motivation. Young children with advanced capabilities and passion for learning may experience derailment if they are not sufficiently challenged or accepted for who they are as learners (Porath, 2009). Nodal, or transition, points in development, such as school entry, are points at which interventions may be most effective (Horowitz, 2009). Horowitz emphasized that these points "do not necessarily occur at the same age point for all individuals" (p. 7). Nor is age the only consideration. This complex, diverse group of children differs in terms of their learning profiles, and the match between learning profile and school expectations must be considered.

\section{Learning Profiles}

Many young children's talents are clearly apparent to the adults in their lives, and the children present profiles to schools that match what schools value - social skills, emotional maturity, orientation to adults, ability to focus, curiosity, and facility with language (Claxton \& Meadows, 2009). Louisa, age 6, loved reading, writing, spelling - anything to do with language - and she was perceived as a model student by her school because of her positive personality and her academic achievements. She bubbled over with enthusiasm at the idea of telling a story to a researcher she barely knew (Porath, 1996) ${ }^{1}$, with the following result:

This is called "The Leprechaun's Gold." One day there was a little girl. She really wanted to find out if there was really a pot of gold at the end of the rainbow. She really wanted to have a pot of gold. She dreamed she could be a big queen one day. She would rule the whole world. She really liked that thought. So every day she would go out into the forest which was where she lived and when she would see a rainbow she would always look for the end of it.

One day as she was looking for it, her mother called to her, "Your lunch time's ready." And then she rushed towards and said, "Mommy, can you put my lunch in a little bag? I want to find the gold at the end of the rainbow." Well, her mother was a very kind woman so she packed her a lunch and said, "Be off with you." And then she scurried off. It had been raining a fair bit and the sun was shining while it was raining so she looked and there was the rainbow. She followed it and suddenly she found a big cave full of gold.

Little did she know there was a snake hungrily waiting for her. She really wanted it so she jumped in. Because she had been so happy she threw her apple down in the gold and it hit the snake's head. And the snake gave up on her. It died. And she was rich. Then her and her mother lived happily ever after. (p. 285)

\footnotetext{
${ }^{1}$ The final, definitive version of this paper has been published in the Journal for the Education of the Gifted, 19, 1996 by SAGE Publications Ltd., All rights reserved. (C) SAGE Publications. http://www.sagepub.com/journals/Journal202068\#tabview=title
} 
Louisa was "skilled-up" (Claxton \& Meadows, 2009, p. 7) in ways that schools value. But what about children whose talents are less obvious, who are less "skilled-up" in the ways of school learning? Peter, also 6, appeared to lack linguistic fluency due to articulation problems. He also demonstrated "6-year-old behaviour" by falling off his chair when he didn't want to pursue a task. However, when asked to tell a story about a little boy his age who had a problem he wanted to solve, Peter wove together evocative language and rhymed couplets in an exciting story of space exploration involving building a space ship to rescue another little boy who had ventured into space:

I think I'll build one - a space ship. So he built it with mighty guns, armour, platoons, everything....He zoomed off...but once he got there, the planet's atmosphere started to burn....Gold went down like a shooting star, like a bullet from the sky...flying like a flaming jet from powers of the universe. Things were smashing... all guys were clashing.... (Porath, 1988)

Without the opportunity to demonstrate his abilities, Peter might be seen as an average or even below average student. But, in telling his story, there was a "magic moment" (Koshy, 2009, p. 159 ) in which his ability to use language in powerful ways and his scientific understanding became apparent. Does this constitute, for Peter, a nodal point in his schooling? If so, what provisions should be made for him? Is his language ability enough? Does his ' 6 -year-old behaviour' hinder his capacity to profit from an intervention focused on his language ability?

\section{Social-Emotional Development}

One of the primary considerations in determination of school readiness is social and emotional maturity - essentially the ability to adjust to and cope successfully with a new set of interpersonal demands and routines. Lucas appeared to have such maturity. He sought out peers to whom he could relate, indicating skill in initiating social contact. However, the fact that he had difficulty relating to his age peers might be perceived as social immaturity or poor adjustment as might his preference for older friends and adult company (Janos \& Robinson, 1985). These perceptions beg the question of what we mean by peers.

Janos and Robinson (1985) emphasized, "'Peerness' rests largely in the degree to which the complexity of children's behavior is matched" (p. 170). Lucas attempted this match by himself, indicating his ability to adjust. Unfortunately, perceptions of efforts such as these usually are negative with the outcome that advanced academic needs are not attended to until social behaviours align with prevailing expectations (Keating, 1991).

In general, young gifted children are well adjusted and socially and emotionally mature (Robinson \& Noble, 1991). They may, however, still demonstrate a relative discrepancy between their social-emotional and cognitive development typical of the asynchronous pattern of development in gifted children. When this relative discrepancy is perceived as proof that the child is not gifted - a perception driven by a belief that giftedness means gifted in everything and at all times - or needs to be supported in building social skills before academic challenge is considered, provision of appropriate educational programs is compromised (Keating, 1991).

\section{Beliefs Affecting Educational Programming}

One of the myths about giftedness that predominates among educators is that no special educational provisions are needed for developmentally advanced children until giftedness 'stabilizes' in middle childhood. Until this time, it is thought, young gifted children will have their 
needs met in primary classrooms where individual developmental trajectories are well understood and/or they will get what they need (i.e., 'make it on their own') because of their intellect and social-emotional maturity (Goelman et al., 2003). It is unclear what stabilization means in this context. In part, the notion may be fueled by the unreliability of intelligence testing in early childhood (Robinson, 2000); distrust of a test result that could change can lead to reluctance to accommodate advanced development. In addition, "Tests may fail to detect children who score below the requisite cutoff...but who may emerge as gifted on subsequent tests because individuals' scores can fluctuate upward as a result of the lack of perfect reliability" (Gottfried et al., 2009 , p. 49). Teachers are uncomfortable with using such indicators to infer ability (Claxton \& Meadows, 2009).

Another belief that impacts on educational decision making for young gifted children is that developmental advancement is believed to 'level off' such that others catch up to the gifted child (Goelman et al., 2003). This may be true if giftedness is defined as high IQ. If one thinks of giftedness this way, "in the absence of intervention [emphasis added], IQ scores of gifted children will inevitably regress toward the population mean" (Gottfried et al., 2009, p. 49). It is important to remember that, due to the complexity of development, there is "no accurate prediction across the lifespan" (Horowitz, 2009, p. 6).

Decisions premised on test scores are understandably difficult for schools to make. Compounding the issues raised above is the inability of intelligence test scores to inform curricular planning (although they are, in some cases, important in calling attention to the reality of gifted level development; Keating, 1991; Matthews \& Foster, 2009). Test scores are very often used to identify children as gifted rather than to highlight their need for some form of educational accommodation. "If high ability and potential are to be recognized early, they should not be used to classify children as gifted, but rather their recognition should enable these competencies to be nurtured appropriately" (Gottfried et al., 2009, p. 53). The imperative associated with early recognition of advanced development is how to respond (Tomlinson et al., 2003).

\section{Educational Affordances}

Consistent with contemporary developmental perspectives on giftedness is a developmental approach to educational planning (Dai, 2010). This approach affords optimal educational opportunities for gifted learners. Programs that are matched to the developmental levels of gifted learners (and all learners) sustain their interest and excitement about learning, support and extend their achievements (Freeman, 2000; Robinson, Abbott, Berninger, Busse, \& Mukhopadhyay, 1997), and support social-emotional development (Keating, 1991). Without this support, the 'stabilization' that is predicted by schools may not be stabilization at all but rather the result of a less than supportive and challenging educational environment. There is the danger of school being too easy; all students need to have their minds perceived as "developing muscles" (Claxton \& Meadows, 2009, p. 5). Similarly, 'leveling off' may be the result of children hiding their abilities to fit in with the status quo or demonstrating average performance because they are underchallenged. Even the most intrinsically motivated learners need support to sustain that motivation (Bereiter \& Scardamalia, 1986), and gifted children, by the time they reach school entry age, have been highly motivated learners for some time. Central to thinking about the fit between child and educational environment is the assumption that giftedness is an "immediate phenomenon" (Dai, 2010, p. 22). Predictive arguments are not salient; meeting children where they are developmentally is the most salient framework for educational decision making. 
A developmental approach may imply testing for level of academic achievement using tests with sufficient ceiling to capture advanced level abilities (Matthews \& Foster, 2009) and/or out-of-level testing to indicate just how advanced a young learner may be (Muratori et al., 2006). Curriculum-based assessment and the use of portfolios, process-folios (Gardner, 1983), and documentation of learning (Rinaldi, 2001) are important supplements to standardized tests that allow for more precise understanding of where children are capable of working in local curricula and how they learn best. An important criterion for judging the worth of an assessment approach is its capability to assist "decisions based on advancing the needs of students, solidly grounded in evidence of emergent excellence or potential for excellence for a particular human endeavor" (Dai, 2010, p. 193).

A developmental approach to giftedness is not only about curricular match and appropriate assessment. It also considers the environmental and social affordances (Dai, 2010) that interact with abilities. Abilities are "induced and shaped by environmental and social affordances and constraints" (Dai, 2010, p. 22). The educational environment can support and even discover giftedness (Hymer, 2009) or constrain its realization and development through policy and pedagogy that fails to recognize and support advanced level development.

The intense interest and advanced ability of the young mathematicians described above were not matched by an equally mature ability to write down or describe mathematical procedures. Should their abilities to describe and/or write down their thinking be considered components of readiness for school? If early schooling emphasizes and values printing and the skill of 'writing down,' there are two possible outcomes. Children may underachieve because mental capacity is taken up by the physical act of writing (see Stoeger, Ziegler, \& Martzog, 2008) and/or they may learn that description and 'writing down' are more valued than big ideas.

\section{Conclusion}

If young children enjoy their early school experiences they tend to continue to seek challenge in their learning (Tomlinson et al., 2003). How do we ensure that young gifted children are sufficiently challenged and well supported when they enter school? Are there policies that should be in place to make certain that chronological age is not the primary determinant of developmental status (Gottfried et al., 1994) and readiness for school?

At present, there are usually no explicit policies regarding early school entrance (Colangelo et al., 2004). The decision to allow early entrance is a difficult one and is hard to reverse (Colangelo et al., 2004). Would it have worked for Lucas? Of course, such a predictive question is inappropriate. However, thinking about Lucas' pattern of development may allow other critical questions to be asked. If he was permitted to start school early, how early is appropriate? Terence Tao, considered a mathematical prodigy and now an accomplished mathematician, reflected on his early start in primary school at the age of 3, "After several weeks, they [his parents] pulled me out as I was clearly not ready" (Muratori et al., 2006, p. 309). Terence did, however, begin skipping grades at 5 and reported satisfaction with his early educational experiences:

I'm pretty satisfied; I may not have gotten my life experiences at the same pace or order as most people, but I did end up with a well-rounded education and finally found my peer group in graduate school and beyond. (Muratori et al., 2006, p. 310)

Lenhard $\mathrm{Ng}$, also considered a mathematical prodigy and an equally accomplished mathematician, on the other hand, skipped a grade only once (Muratori et al., 2006). Subject acceleration was, however, part of his educational life, as it was with Terence Tao. He said, "It seems to me 
that my parents struck a good balance between keeping me challenged and allowing me to progress as a normal kid" (Muratori et al., 2006, p. 316). Subject acceleration could allow students like Lucas to experience optimally matched curriculum among older peers while, at the same time, giving him the opportunity to be part of an age-related peer group, a factor that may be important in adolescence when gifted children who have been accelerated by grade may experience feelings of marked difference from their peers (Janos \& Robinson, 1985).

In terms of the educational environment, affordance is believed to be optimal in environments that are flexible, responsive to diverse developmental needs as they exist when children enter school, and complex. Complexity implies not only complex, challenging instructional tasks but also breadth and richness of opportunities for students to demonstrate their abilities. Barab and Plucker (2002) emphasized smart contexts in the determination of intelligent behaviour since intelligence is situated in context. This focus on smart contexts aligns with a developmental approach to giftedness that considers individual developmental trajectories, developmental trajectories in different domains (e.g., outstanding abilities in mathematics are evident much earlier in development than are those in philosophy [Feldman, 1986]; early skill-based precocity in music does not necessarily carry one through adolescence when conceptual understanding of music theory is required [Bamberger, 1986]), and the possibility of changing expressions of giftedness over the life span (Jackson, 2000). A framework for decision making consistent with the developmental approach and appropriate educational affordances uses "person-in-context" as the unit of analysis (Dai, 2010, p. 222).

What characterizes educational environments that would be considered smart and take the child in those environments as their unit of analysis? Given contemporary understandings of different forms of giftedness that unfold according to different developmental trajectories; the acknowledgement that giftedness may not become apparent without a rich, nurturant environment; and the individual, familial, and environmental differences that interact with abilities, it is clear that educational environments need to pay close attention to the child in context. In our multicultural, global communities it is necessary to be aware of the role culture plays in shaping understandings of giftedness and the aims of education (see Phillipson \& McCann, 2007).

As yet, we have no definitive answers to the contexts that support children like Lucas, Louisa, and Peter. We have broad understandings of the complexity of human intelligence and its development, the variety of pathways to accomplishment, and the needs of young gifted children. We also have important questions about how to meet these needs stemming from extant literature. As a general principle, these understandings and questions suggest flexible, child-centered educational practices, but we need a research agenda that focuses on questions concerning the factors that contribute to supporting diversity in development before clear educational policies can be crafted. For example, case studies of schools that attend to the child in context, offer flexible options for supporting children who are developmentally advanced and provide rich opportunities for gifts to blossom would inform broader consideration of the factors that facilitate decision-making about children in context. What are the administrative and pedagogical philosophies in such schools? What practices follow a 'child-in-context' approach? Is early school entrance an option? If so, what is the rationale and how are decisions made? How are the perspectives of the child, family, and school taken into account? How do school personnel view their readiness to support all children's developmental diversity? The child-in-context framework holds promise in crafting educational policy and decisions that are premised on supporting all children to understand and achieve excellence whenever they enter school, but details are needed to make the framework accessible more broadly. 


\section{References}

Bamberger, J. (1986). Growing up prodigies: The midlife crisis. In D. H. Feldman (Ed.), Developmental approaches to giftedness (pp. 265-279). San Francisco, CA: Jossey-Bass.

Barab, S. A., \& Plucker, J. A. (2002). Smart people or smart contexts? Cognition, ability, and talent development in an age of situated approaches to knowing and learning. Educational Psychologist, 37, 165182. doi:10.1207/S15326985EP3703_3

Bereiter, C., \& Scardamalia, M. (1986). Educational relevance of the study of expertise. Interchange, 17(2), 10-19. doi:10.1007/BF01807464

Birch, J. W. (1954). Early school admission for mentally advanced children. Exceptional Children, 21, 84-87.

Bruner, J. (1996). The culture of education. Cambridge, MA: Harvard University Press.

Caprara, G. V., Barbaranelli, C., Pastorelli, C., Bandura, A., \& Zimbardo, P. G. (2000). Prosocial foundations of children's academic achievement. Psychological Science, 11, 302-306. doi:10.1111/1467-9280 .00260

Claxton, G., \& Meadows, S. (2009). Brightening up: How children learn to be gifted. In T. Balchin, B. Hymer, \& D. J. Matthews (Eds.), The Routledge international companion to gifted education (pp. 3-9). New York, NY: Routledge.

Colangelo, N., Assouline, S. G., \& Gross, M. U. M. (2004). A nation deceived: How schools hold back America's brightest students. Vol. 1. Iowa City, IA: The Connie Belin and Jacqueline N. Blank International Center for Gifted Education and Talent Development.

Dai, D. Y. (2010). The nature and nurture of giftedness: A new framework for understanding gifted education. New York, NY: Teachers College Press.

Dale, P. S., Robinson, N. M., \& Crain-Thoreson, C. (1995). Linguistic precocity and the development of reading: The role of extralinguistic factors. Applied Psycholinguistics, 16, 173-187. doi:10.1017 /S0142716400007074

Doherty, G. (1997). Zero to six: The basis for school readiness. Gatineau, QC: HRDC Publications Centre. Retrieved from http://www.hrsdc.gc.ca/eng/cs/sp/sdc/pkrf/publications/1997-002557/page00.shtml

Dweck, C. S. (2009). Foreword. In F. D. Horowitz, R. F. Subotnik, \& D. J. Matthews (Eds.), The development of giftedness and talent across the life span (pp. xi-xiv). Washington, DC: American Psychological Association.

Dweck, C. S., \& London, B. (2004). The role of mental representation in social development. Merrill-Palmer Quarterly, 50, 428-444. doi:10.1353/mpq.2004.029

Eisenberg, N. (1992). The caring child. Cambridge, MA: Harvard University Press.

Feldman, D. H. (1986). Nature's gambit: Child prodigies and the development of human potential. New York, NY: Basic Books.

Fischer, K. W., \& Canfield, R. L. (1986). The ambiguity of stage and structure of behavior: Person and environment in the development of psychological structure. In I. Levin (Ed.), Stage and structure: Reopening the debate (pp. 246-267). Norwood, NJ: Ablex.

Fischer, K. W., Knight, C. C., \& Van Parys, M. (1993). Analyzing diversity in developmental pathways: Methods and concepts. In R. Case \& W. Edelstein (Eds.), The new structuralism in cognitive development: Theory and research on individual pathways (pp. 33-56). Basel, Switzerland: Karger.

Freeman, J. (2000). Teaching for talent: Lessons from the research. In C. F. M. van Lieshout \& P. G. Heymans (Eds.), Developing talent across the life span (pp. 231-248). Hove, England: Psychology Press.

Gardner, H. (1983). Frames of mind. The theory of multiple intelligences. New York, NY: Basic Books.

Goelman, H., Andersen, C. J., Anderson, J., Gouzouasis, P., Kendrick, M., Kindler, A.,...Koh, J. (2003). Early childhood education. In W. M. Reynolds \& G. E. Miller (Eds.), Editor-in-Chief: I. B. Weiner, Comprehensive handbook of psychology. Volume 7: Educational Psychology (pp. 285-331). New York, NY: John Wiley \& Sons.

Golomb, C. (1992). The child's creation of a pictorial world. Berkeley, CA: University of California Press.

Gottfried, A. W., Gottfried, A. E., Bathurst, K., \& Guerin, D. W. (1994). Gifted IQ: Early developmental aspects. The Fullerton longitudinal study. New York, NY: Plenum Press.

Gottfried, A. W., Gottfried, A. E., \& Guerin, D. W. (2009). Issues in early prediction and identification of intellectual giftedness. In F. D. Horowitz, R. F. Subotnik, \& D. J. Matthews (Eds.), The development of 
giftedness and talent across the life span (pp. 43-46). Washington, DC: American Psychological Association.

Hobson, J. (1948). Mental age as a workable criterion for school admission. Elementary School Journal, 48, 312-321. doi:10.1086/458948

Horowitz, F. D. (2009). Introduction: A developmental understanding of giftedness and talent. In F. D. Horowitz, R. F. Subotnik, \& D. J. Matthews (Eds.), The development of giftedness and talent across the life span (pp. 3-19). Washington, DC: American Psychological Association.

Hymer, B. J. (2009). Beyond compare? Thoughts towards an inclusional, fluid and non-normative understanding of giftedness. In T. Balchin, B. Hymer, \& D. J. Matthews (Eds.), The Routledge international companion to gifted education (pp. 299-307). New York, NY: Routledge.

Jackson, N. E. (2000). Strategies for modeling the development of giftedness in children. In R. C. Friedman \& B. M. Shore (Eds.), Talents unfolding: Cognition and development (pp. 27-54). Washington, DC: American Psychological Association.

Janos, P. M., \& Robinson, N. M. (1985). Psychosocial development in intellectually gifted children. In F. D. Horowitz \& M. O'Brien (Eds.), The gifted and talented: Developmental perspectives (pp. 149-195). Washington, DC: American Psychological Association.

Janus, M., Hughes, D., \& Duku, E. (2010). Patterns of school readiness among selected subgroups of Canadian children: Children with special needs and children with diverse language backgrounds. Canadian Council on Learning. Retrieved from http://www.offordcentre.com/readiness/

Junoven, J., \& Wentzel, K. R. (Eds.). (1996). Social motivation: Understanding children's school adjustment. New York, NY: Cambridge University Press.

Keating, D. P. (1991). Curriculum options for the developmentally advanced: A developmental alternative to gifted education. Exceptionality Education Canada, 1, 53-84.

Koshy, V. (2009). Too long neglected: Giftedness in younger children. In T. Balchin, B. Hymer, \& D. J. Matthews (Eds.), The Routledge international companion to gifted education (pp. 155-159). New York, NY: Routledge.

Liben, L. S. (2009). Giftedness during childhood: The spatial-graphic domain. In F. D. Horowitz, R. F. Subotnik, \& D. J. Matthews (Eds.), The development of giftedness and talent across the life span (pp. 5974). Washington, DC: American Psychological Association.

Louis, B., \& Lewis, M. (1992). Parental beliefs about giftedness in young children and their relation to actual ability level. Gifted Child Quarterly, 36, 27-31. doi:10.1177/001698629203600107

Lubinski, D., \& Benbow, C. P. (2000). States of excellence. American Psychologist, 55, 137-150. doi:10.1037 /0003-066X.55.1.137

Matthews, D. J., \& Foster, J. F. (2009). Being smart about gifted education: A guidebook for educators and parents. Scottsdale, AZ: Great Potential Press.

Morelock, M. J. (1996). On the nature of giftedness and talent: Imposing order on chaos. Roeper Review, 19, 4-12. doi:10.1080/02783199609553774

Muratori, M. C., Stanley, J. C., Ng, L., Ng, J., Gross, M. U. M., Tao, T., \& Tao, B. (2006). Insights from SMPY's greatest former child prodigies: Drs. Terence ("Terry") Tao and Lenhard ("Lenny") Ng reflect on their talent development. Gifted Child Quarterly, 50, 307-324. doi:10.1177/001698620605000404

Neihart, M. (2007). The socioaffective impact of acceleration and ability grouping: Recommendations for best practice. Gifted Child Quarterly, 51,330-341. doi:10.1177/0016986207306319

Phillipson, S. N., \& McCann, M. (Eds.). (2007). Conceptions of giftedness: Sociocultural perspectives. Mahwah, NJ: Lawrence Erlbaum.

Porath, M. (1988). [Cognitive development in gifted children: A neo-Piagetian approach]. Unpublished raw data.

Porath, M. (1992). Stage and structure in the development of children with various types of "giftedness." In R. Case, The mind's staircase: Exploring the conceptual underpinnings of children's thought and knowledge (pp. 303-317). Hillsdale, NJ: Lawrence Erlbaum.

Porath, M. (1993). Gifted young artists: Developmental and individual differences. Roeper Review, 16, 29-33. doi:10.1080/02783199309553530

Porath, M. (1996). Narrative performance in verbally gifted children. Journal for the Education of the Gifted, $19,276-292$. 
Porath, M. (2000). Social giftedness in childhood: A developmental perspective. In R. C. Friedman \& B. M. Shore (Eds.), Talents unfolding: Cognitive and developmental frameworks (pp. 195-215). Washington, DC: American Psychological Association.

Porath, M. (2009). Educating gifted children: Frameworks for debate. In J. Lupart, A. McKeough, M. Porath, L. Phillips, \& V. Timmons (Eds.), The challenges of student diversity in Canadian schools: Essays on building a better future for exceptional children (pp. 341-373). Markham, ON: Fitzhenry and Whiteside.

Porath, M., \& Lupart, J. (2009). Gifted children's representations of learner identities. Exceptionality Education International, 19, 80-95. Retrieved from http://ejournals.library.ualberta.ca/index.php/eei

Reynolds, M. (Ed.). (1962). Early school admission for mentally advanced children. Washington, DC: Council for Exceptional Children.

Rinaldi, C. (2001). Documentation and assessment: What is the relationship? In C. Giudici, C. Rinaldi, \& M. Krechevsky (Eds.), Making learning visible: Children as individual and group learners (pp. 78-93). Reggio Emilia, Italy: Reggio.

Robinson, N. M. (1987). The early development of precocity. Gifted Child Quarterly, 31, 161-164. doi:10 $.1177 / 001698628703100406$

Robinson, N. M. (1993). Identifying and nurturing gifted, very young children. In K. A. Heller, F. J. Monks, \& A. H. Passow (Eds.), Research and development of giftedness and talent (pp. 507-524). Tarrytown, NY: Pergamon Press.

Robinson, N. M. (2000). Giftedness in very young children: How seriously should it be taken? In R. C. Friedman \& B. M. Shore (Eds.), Talents unfolding: Cognition and development (pp. 7-26). Washington, DC: American Psychological Association.

Robinson, N. M., Abbott, R. D., Berninger, V. W., \& Busse, J. (1996). The structure of abilities in mathprecocious young children: Gender similarities and differences. Journal of Educational Psychology, 88, 341-352. doi:10.1037//0022-0663.88.2.341

Robinson, N. M., Abbott, R. D., Berninger, V. W., Busse, J., \& Mukhopadhyay, S. (1997). Developmental changes in mathematically precocious young children: Longitudinal and gender effects. Gifted Child Quarterly, 41, 145-158. doi:10.1177/001698629704100404

Robinson, N. M., \& Noble, K. D. (1991). Social-emotional development and adjustment of gifted children. In M. G. Wang, M. C. Reynolds, \& H. J. Walberg (Eds.), Handbook of special education: Research and practice (Vol. 4, pp. 23-36). New York, NY: Pergamon.

Robinson, N. M., Zigler, E., \& Gallagher, J. J. (2000). Two tails of the normal curve: Similarities and differences in the study of mental retardation and giftedness. American Psychologist, 55, 1413-1424. doi:10 $.1037 / 0003-066$ X.55.12.1413

Rodari, G. (1973). Grammatica della fantasia. Torino, Italy: Einaudi.

School Readiness to Learn (SRL) Project. (2010). Retrieved from http://www.offordcentre.com/readiness/

Southern, W. T., \& Jones, E. D. (1991). The academic acceleration of gifted children. New York, NY: Teachers College Press.

Sternberg, R. J., \& Davidson, J. E. (2005). Conceptions of giftedness (2nd ed.). New York, NY: Cambridge University Press.

Stoeger, H., Ziegler, A., \& Martzog, P. (2008). Deficits in fine motor skill as an important factor in the identification of gifted underachievers in primary school. Psychology Science Quarterly, 50, 134-146.

Tomlinson, C. A., Brighton, C., Hertberg, H., Callahan, C. M., Moon, T. R., Brimijoin, K.,...Reynolds, T. (2003). Differentiating instruction in response to student readiness, interest, and learning profile in academically diverse classrooms: A review of literature. Journal for the Education of the Gifted, 27, 119-145.

Waxman, R., Robinson, N. M., \& Mukhopadhyay, S. (1996). Parent nurturing math-talented young children. Storrs, CT: The National Research Center on the Gifted and Talented.

Winner, E. (1996). Gifted children: Myths and realities. New York, NY: Basic Books.

Winner, E. (2009). Toward broadening our understanding of giftedness: The spatial domain. In F. D. Horowitz, R. F. Subotnik, \& D. J. Matthews (Eds.), The development of giftedness and talent across the life span (pp. 75-85). Washington, DC: American Psychological Association. 


\section{Author's Note}

Correspondence concerning this article should be addressed to Marion Porath, Department of Educational and Counselling Psychology, and Special Education, The University of British Columbia, 2125 Main Mall, Vancouver, BC V6T1Z4. E-mail: marion.porath@ubc.ca 